\title{
Prevalência de condenas em abatedouros bovinos com inspeção estadual no Alto Uruguai Gaúcho
}

Greiciele Hoffmann Pessoa;, Eduarda Cesari, Elien Eduarda Favaretto, Rodrigo Dalmina Rech, Sonara Alves da Silva, Diego

Morgan Dellagostin, Ricardo Visentini, Deise Luiza Mahl,Angela Faccin, Daniela dos Santos Oliveira

Instituto de Desenvolvimento Educacional do Alto Uruguai (IDEAU), Caxias do Sul, RS, Brasil

*Autor correspondente

e-mail: greici.pessoa@hotmail.com

\section{Resumo}

Por apresentar o maior rebanho mercantil do mundo, o Brasil tem condição excepcional no cenário da bovinocultura, possuindo todas as qualidades para o departamento de carnes e derivados e uma maior participação no mercado internacional. Foram visitados três abatedouros de bovinos (A, B e C), inspecionados pela Coordenadoria de Inspeção Sanitária dos Produtos de Origem Animal (CISPOA), no Alto Uruguai Gaúcho. Na visita acompanhou-se todo o fluxograma de abate, desde a inspeção ante-mortem até a parte de cortes da carcaça. Foram feitas três visitas no total, uma em cada estabelecimento, onde coletou-se dados e imagens dos achados na inspeção. Os dados de condena foram tabulados e expressos em porcentagem, realizando uma análise comparativa entre os frigoríficos e as principais lesões encontradas. Obtiveram-se os dados das principais lesões e condenas mais prevalentes nos abates, no período de um ano, compreendido entre agosto de 2015 a agosto de 2016. Com base nos dados obtidos constatou-se que nefrite foi a maior causa de condenações no abatedouro A no período avaliado, apresentando-se por lesões que se caracterizam macroscopicamente como pequenas manchas amareladas a acinzentadas, geralmente distribuídas por todo o rim, o que dá uma aparência irregular à superfície do mesmo. A congestão foi a maior causa de condena no abatedouro B, sendo que no abatedouro A foi a terceira mais prevalente e no abatedouro C destacou-se como a segunda maior causa de condenam; sendo que nestas lesões são observados aumento de volume e coloração escura do órgão, ao corte constata-se acúmulo de sangue. Ao analisar os dados, nota-se que as condenas pela presença de quisto urinário destacou-se em relação às outras causas, estando como a principal causa de condenação no abatedouro C; estas lesões se caracterizam por apresentarem uma cápsula transparente ou esbranquiçada e opaca, que contém líquido semelhante à urina. Ainda foi observada condenação de órgão ou carcaças parciais ou totais por outras causas importantes como migração larval, presença de abscessos 
e contaminação de carcaça É essencial a presença da Inspeção Sanitária nos abatedouros para que ocorra o cumprimento da legislação, garantindo que os produtos procedentes do abate cheguem ao consumidor final livres de alterações que possam comprometer sua qualidade, pondo em risco a saúde da população. Assim, no período de inspeções analisado, obteve-se como destaque de condenas no abatedouro A a presença de nefrites, no abatedouro B, aspectos de congestão, e no abatedouro $C$, achados de quisto urinário. 